Witz, Anekdote usw. План змісту гумору фіксується у контекстуальній оболонці діалогічної або монологічної форми представлення комічної ситуації. План вираження формується через знакову та асоціативну природу структури гумору у результаті процесів вербалізації.

Перспективним вбачаються питання щодо виявлення семантичних та структурних шляхів формування пріоритетних ідентифікаторів комічного у німецькій мові.

\title{
Література:
}

1. Пропп В. Я. Проблемы комизма и смеха. М. : Искусство, 1976. $182 \mathrm{c}$.

2. Lipps Th. Komik und Humor. Lpz., 1922. 67 S.

3. Raskin V. The Semantic Mechanisms of Humor. Reidel : Dordrecht, 1985. $280 \mathrm{p}$.

4. Duden 12. Zitate und Aussprüche. Dudenverlag : Mannheim. Leipzig. Wien. Zürich., 2002. 960 S.

DOI https://doi.org/10.30525/978-9934-26-073-5-1-57

\section{ВИВЧЕННЯ ІНОЗЕМНОЇ ПРОФЕСІЙНОЇ ЛЕКСИКИ У ВНЗ}

\author{
Іванова T. B. \\ викладач кафедри іноземних мов професійного спілкування \\ Міжнародного гуманітарного університету \\ м. Одеса, Украӥна
}

В останні роки вивчення англійської мови в вищих навчальних вузах набуває особливого значення. Світ вступив в епоху глобалізації тому йому потрібні фахівці, здатні плідно працювати в умовах глобалізації. Випускники вузів, які в подальшому будуть вирішувати важливі завдання соціально-економічного розвитку країни та модернізації економіки, повинні не тільки володіти знаннями $з$ фахової спеціальності та вивчення іiі дисциплін, а й володіти міжнародною мовою тобто англійською. Для того щоб випускник вузу міг читати літературу за фахом і спілкуватися зі своїми зарубіжними колегами на професійному рівні, йому необхідно добре знання не тільки загальновживаної, але i професійної лексики.

Лексика є важливим компонентом мовленнєвої діяльності. Від рівня володіння лексичною стороною мовленнєвої діяльності в значній мірі 
залежить рівень комунікативних компетенцій. Опанування професійної лексики, таким чином, $є$ необхідною умовою, при якому має місце адекватне розуміння отриманої і переданої інформації в ході професійної діяльності.

Практичний досвід показує, що оволодіння професійною лексикою $є$ серйозною проблемою для багатьох студентів молодших курсів. Вони вважають цю задачу дуже важкою і приділяють недостатньо часу роботі 3 лексикою. Будуючи власні висловлювання, студенти намагаються уникати вживання нових слів, що вводяться на черговому занятті, прагнуть вживати давно знайомі, звичні слова. Наприклад, використовують слово good, в той час як можна було б сказати efficient (efficient workers), reasonable (reasonable solution), competitive (a competitive price) i т.п. Студенти, чий рівень володіння мовою був спочатку вищим, коли вони прийшли до вузу, швидше і легше запам'ятовують нові слова, більш активно вживають професійну лексику. Але i тут виникають проблеми. Студенти обмежують вживання нової лексики лише тим заняттям (текстом), на якому вона була введена. Іншими словами, ці студенти успішно відповідають на питання до тексту підручника, виконують лексичні вправи з опорою на даний текст, такі Give English equivalents for the following word combinations, Insert the missing words, Use your active vocabulary, Paraphrase the following words and expressions using your active vocabulary i т.п. Вони швидко знаходять потрібні лексичні одиниці, але, виходячи за рамки підручника (наприклад, працюючи з іншим матеріалом), немов забувають про них. У новому тексті іноді виявляються невпізнаними ті слова, які тільки що використовувалися в тексті підручника. Відповідаючи на питання, обмінюючись думками з приводу прочитаного, студенти знову звертаються до давно знайомим словами зі шкільного курсу, уникаючи використання активної лексики уроку в нової ситуації. Виникає страх та невпевненість. Причин може бути декілька. По-перше, переходячи зі школи до вузу, учні переживають період академічної адаптації, тобто відчувають труднощі в умовах нової для них педагогічної системи. По-друге, сам мовний матеріал на заняттях $з$ англійської мови істотно відрізняється від шкільного матеріалу. Замість цікавих текстів і лексичних одиниць, які називають знайомі предмети і явища повсякденного життя, учні читають професійно - спрямовані тексти, які містять абсолютно нові для них слова. Можливо, однією з причин $є$ те, що студент ще не має чіткої професійної орієнтації, мало знає про майбутню спеціальність, не назбирав ще знань зі спеціальних дисциплін, і йому важко говорити на професійні теми навіть рідною мовою , не кажучи вже англійською. 
Дуже часто викладач іноземної мови стикається 3 тим, що його студенти абсолютно не готові обговорювати питання, які пов'язанні 3 його майбутньою професією іноземною мовою. Таким чином, перед викладачем постає проблема: як домогтися того, щоб студенти активізували новий лексичний матеріал? Як допомогти студентам подолати страх перед новими мовними ситуаціями?

Перед викладачем стоїть не тільки освітнє, а й виховне завдання: підвищити мовні компетенції учнів i одночасно формувати їх професійний інтерес і усвідомлення практичної значущості отриманих знань для майбутньої професійної діяльності. Вирішуючи цю двоєдину задачу, викладач виходить 3 того, що головне полягає не в засвоєнні кількості знань про саму мову, а в формуванні та розвитку навичок користуватися іноземною мовою як засобом спілкування.

Дуже важливо переконати студентів в тому, що мова не обмежується рамками підручника, що підручник - це лише засіб, який допомагає отримати знання, придбати необхідні вміння та навички а в регулярному використанні та застосуванні досліджуваної лексики в реальних життєвих ситуаціях і почати активно використовувати певні лексичні одиниці в нових ситуаціях за межами підручника. Завдання викладача організувати, контролювати і оцінювати хід роботи на занятті.

На підготовчому етапі роботи необхідно підібрати відповідний текст. Вибираючи текст, враховуємо такі фактори: професійна спрямованість, пізнавальна цінність, обсяг, комунікативна цінність, доступність за мовним оформленням. Робота над текстом це тільки 50\% засвоєння нової професійної іноземної лексики. Викладач на протязі усього заняття надає студентам завдання на засвоєння досліджуваної лексики. Наприклад, хтось повинен розробити сценарій діалогу 3 урахуванням запропонованих викладачем ролей і ключових слів, інші виконують запропоновані ролі. Під час роботи особливу увагу студентів зосереджено на тій лексиці, яку слід активізувати. студенти бачать потрібну лексику в новому тексті, складають з цими словами речення, використовують їх в своїй промові. Під час виступу викладач не виправляє кожне слово, даючи студентам висловитися. Виправляються лише ті помилки, які заважають акту комунікації. Після виступу викладач оцінює роботу студентів, відзначаючи сильні сторони (цікаво розроблений сценарій, використання здебільшого обов'язкової лексики, якісне виконання і т.п.) i коментуючи недоліки (серйозні помилки у вимові окремих слів, недостатньо активне використання лексичних засобів і т.д.). Контроль засвоєнного матеріалу викладач може подати у вигляді аудіювання. Під час прослуховування студентам можна запропонувати певні вправи. 
зазвичай, це вправи на вміння орієнтуватися в тексті, на пошук специфічної інформації. Студентів забезпечують роздатковим матеріалом. Це таблиці, графіки або діаграми, які потрібно заповнити під час прослуховування. Це також може бути текст 3 пропущеними словами професійного значення, які треба вставити під час прослуховування. Це можуть бути вправи, які мають на меті підтвердити або спростувати інформацію (вірно / невірно), підібрати правильну ілюстрацію (картинку, графік, діаграма, і т.п.) до тексту, вибрати правильний варіант відповіді 3 декількох варіантів на поставлене запитання, чи правильний варіант тлумачення затвердження, вправи на упорядкування пунктів плану або частин тексту. Можна також запропонувати підібрати заголовок до тексту (або окремих його частин) 3 ряду запропонованих. Поступово вправи ускладнюються і перевіряють більш детальне розуміння аудіоматеріалу. Це вправи: вставити пропущені слова і словосполучення, співвідносити слово 3 його визначенням, ідею з частиною тексту, дві частини тексту між собою, причину із слідством, визначити основну ідею, відповісти на питання, скласти план, переказ тексту. Ще більш детальне розуміння матеріалу передбачає завдання на творчу переробку тексту, коментування його змісту, узгодження з ідеями тексту або їх критики, висловлювання свого бачення проблеми, і т.П. Метою цих завдань $є$ використання лексики прослуханого професійного тексту при виконанні різних семантичних, лексичних або граматичних вправ. Вони $\epsilon$ тим мостом, який забезпечує плавний перехід засвоєння одного мовного навику до іншого. За допомогою таких вправ можуть вироблятися навички говоріння (обговорення прослуханого або відповіді на питання), листи (переклади або інші письмові вправи) і навіть читання (використання друкованих записів текстів вже після їх прослуховування).

Підводячи підсумок, слід щоразу вказувати на практичну значимість досліджуваної лексики. Завдання може видозмінюватися від заняття до заняття, тому що кожен новий текст дає нові можливості, але суть завжди одна: продемонструвати навчальний матеріал, в даному випадку професійну лексику, в новій, реальної ситуації (поза підручника), і поставити студента перед необхідністю скористатися нею в ситуації спілкування. Практика показала, що даний прийом допомагає студенту усвідомити лексичні одиниці як факти мови, що мають практичне значення для майбутньої професійної діяльності, а не просто як навчальний матеріал, обов'язковий до заучування. Регулярно працюючи над такими «міні-проектами» на заняттях, цілеспрямовано слухаючи новини рідною та англійською мовами, поповнюючи свої знання про обраний фах і накопичуючи знання за фахом на профільних предметах, 
студенти поступово отримують уявлення про те, де, коли і як вони можуть скористатися професійною іноземною лексикою.

Висловлюючись на професійні теми, студенти активніше використовують відповідну лексику. Підводячи підсумки атестації, завжди слід відзначати особистий прогрес кожного. Приріст «навчального продукту» у всіх, зрозуміло, різний, але факт приросту відзначається у всіх, хто регулярно відвідував заняття. На закінчення ще раз підкреслимо, що в процесі вивчення професійної лексики на заняттях з англійської мови у студентів «... формується соціокультурна іншомовна компетенція, необхідна для успішної професійної діяльності в іншомовному середовищі, 3 представниками різних культур.

\title{
Література:
}

1. Суркова Е.В., Вишневецкая Н.А., Романова О.Н. Психолингвистические особенности смыслового восприятия иноязычного профессионального на слух и формирование аудитивной компетенции студентов // Бизнес. Образование. Право. В 2. Сальная Л.К. Обучение аудированию научной речи// Известия ЮФИ. Технические науки. 2013. №10. С. 126-131.

2. Михайлова В. Обучение профессионально ориентированной лексики специалистов вузов// Вестник ТГПУ. 2013. № 9. С. 104-107.

3. Николаева Н. Особенности обучения аудированию профессиональных текстов на английском языке в техническом вузе // Вопросы современной науки и практики. 2015. №3(57). С. 201-208.Вестник Волгоградского института бизнеса. 2016. № 2 (35). С. 275-279.

DOI https://doi.org/10.30525/978-9934-26-073-5-1-58

\section{VERBALIZATION OF THE EPISTEMIC FACTOR IN TOPIC CONTEXTUALIZATION}

\author{
Kovalchuk L. V. \\ Candidate of Philological Sciences, \\ Senior Lecturer at the English Philology Department \\ Lesya Ukrainka Volyn National University \\ Lutsk, Ukraine
}

Within the framework of the current cognitive-communicative paradigm there is a general tendency of rethinking context and defining it not as an 218 